\title{
PENGARUH FUNGSI MANAJEMEN \\ TERHADAP PRODUKTIVITAS KERJA DOSEN UNIVERSITAS BUANA \\ PERJUANGAN KARAWANG
}

\author{
Aji Tuhagana \\ Program Studi Manajemen \\ Universitas Buana Perjuangan Karawang \\ Aji.tuhagana@ubpkarawang.ac.id
}

\begin{abstract}
Abstrak
Penelitian ini bertujuan untuk mengetahui pengaruh fungsi manajemen terhadap produktivitas kerja dosen Universitas Buana Perjuangan Karawang. Data yang diperoleh melalu angket yang disebarkan kepada 52 orang dosen sebagai responden, kemudian diolah melaui bantuan program SPSS 18, diperleh data sebagai berikut :

Hasilkorelasi analisa korelasi dan regresi variabel fungsi manajemen dan variable produktivitas kerja dosen memiliki nilai sebesar 0,662. Artinya arah hubungan kedua variabel tersebut positif, apabila variabel fungsi manajemen naik maka variabel produktivitas kerja dosen juga akan naik, di mana jika semakin baik fungsi manajemen dijalankan, maka produktivitas kerja dosen akan semakin baik pula, begitu juga sebaliknya. Sedangkan korelasi antara variabel X dan Y adalah kuat.

Koefisien determinasi sebesar 0,438, menjelaskan bahwa persamaan regresi yang diperolah dapat menerangkan 43,8\% variasi produktivitas kerja dosen atau bisa dikatakan bahwa persamaan regresi yang diperoleh cukup baik untuk menjelaskan variabel fungsi manajemen. Dari hasil uji statistik diperoleh pengaruh variabel bebas (fungsi manajemen) terhadap variabel terikat (produktivitas kerja dosen) dengan nilai p-value sebesar 0,0005.

Ringkasan Hasil Pengolahan Data Regresi

\begin{tabular}{lccccc}
\hline \multicolumn{1}{c}{ Keterangan } & $\boldsymbol{B}$ & Standar Eror & $\boldsymbol{t}_{\text {hitung }}$ & Sig & Keterangan \\
\hline Constant & 20,843 & 7,457 & 2,795 & 0,007 & Signifikan \\
Fungsi Manajemen $(X)$ & 0,695 & 0,111 & 6,248 & 0,0005 & Signifikan \\
Nilai $R=0,662$ & Sig F $=0,0005$ & & Jumlah Sampel $=52$ \\
Nilai $R^{2}=0,438$ & F hitung $=39,034$ & & $\alpha$ \\
Persamaan Regresi $Y=0,05$ & \\
Produktivitas Kerja Dosen $=20,843+0,695^{*}$ Fungsi Manajemen $+e$ & \\
\hline
\end{tabular}
\end{abstract}

Hasil analisa statistik terhadap produktivitas kerja dosen dan fungsi manajemen, dengan nilai konstan sebesar 20,843 dan nilai $b=0,695$ didapatkan persamaan regresinya sebagai berikut:

$$
\begin{aligned}
Y & =\beta_{0}+\beta_{1} X_{1}+e \\
\text { Produktivitas Kerja Dosen } & =20,843+0,695 * \text { Fungsi Manajemen }+e
\end{aligned}
$$

190. 


\section{Dimana:}

a. Konstanta $\beta_{0}$ sebesar 20,843 artinya jika faktor fungsi manajeman konstan atau sama dengan 0 (nol), maka besarnya produktivitas kerja dosen adalah 20,843 satuan.

b. Nilai $\beta_{1}$ yang merupakan koefisien regresi dari variabel $X_{1}$ (fungsi manajemen) sebesar 0,695 artinya jika terjadi peningkatan fungsi manajemen sebesar 1 satuan, maka produktivitas kerja dosen akan mengalami kenaikan atau peningkatan sebesar 0,695 satuan.

Kata Kunci : Fungsi Manajemen; Produktivitas Kerja

\section{BAB 1}

\section{PENDAHULUAN}

\section{A. Latar Belakang}

Pengelolaan yang terencana dan terorganisir sebuah organisasi, termasuk di dalamnya lembaga pendidikan merupakan suatu yang mutlak diperlukan karena hal tersebut berdampak pada keberlangsungan atau tumbuh dan berkembangnya lembaga pendidikan tersebut. Semua unsur yang terlibat dalam lembaga dituntut untuk dapat berperan aktif dalam pengelolaan. Tuntutan tersebut berdampak pada kebutuhan menerapkan fungsi manajemen secara efektif dan efisien.

Keberhasilan penerapan teori-teori fungsi manajemen pada seluruh elemen lembaga pendidikan ditentukan oleh setidaknya empat elemen yang harus tersedia di dalamnya. Ke empat elemen tersebut harus dapat bergerak secara terintegrasi dan berekesinambungan yakni perencanaan, pengorganisasian, pelaksanaan dari setiap rencana kerja dan kotrol dari setiap tahapan pekerjaan yang telah di lakukan.

Universitas Buana Perjuangan merupakan sebuah lembaga pendidikan tinggi yang baru tumbuh dan sedang berkembang. Dalam proses tumbuh dan berkembangnya, lembaga pendidikan ini walau belum sempurna secara teoritis akan tetapi peletakan dasar dasar fungsi manajemen sudah dilakukan oleh seluruh organ lembaga yang terlibat secara langsung dalam pengelolaan.

Karena Universitas Buana Perjuangan Karawang masih tergolong lembaga pendidikan yang baru berdiri, belum sepenuhnya menjalankan fungsi manajemen. Hal ini dimungkinkan dapat menimbulkan dampak pada produktivitas kerja dosen yang dimilikinya. Dari seluruh dosen tetap yang Universitas Buana Perjuangan, belum seluruhnya memiliki nomor induk nasional (NIDN). Adapun dosen yang 
sudah memiliki nomor induk nasional, belum seluruhnya memiliki jabatan fungsional dan dari seluruh dosen yang memilki jabatan fungsional, belum seluruhnya memilki sertifikasi pendidik (sertifikasi dosen). Akan tetapi meskipun demikian, berdasarkan data yang ada di lapangan, dari seluruh sumberdaya manusia yang terlibat di dalamnya sudah memenuhi aspek kubutuhan yang telah dipersyaratkan oleh pemerintah terkait.

Terlepas dari masih banyak kekurangan yang ada di Universitas Buana Perjuangan Karawang ini, para proses tumbuh kembangnya, lembaga ini memilki potensi yang sangat tinggi untuk berkembang menjadi pendidikan tinggi yang dapat diperhitungan

Berdasarkan fenomena tersebut di atas, penulis akan melakukan penelitian di Universitas Buana Perjuangan Karawang pada bidang manajemen dengan mengangkat judul penelitian "Pengaruh Fungsi Manajemen Terhadap Produktivitas Kerja Dosen Universitas Buana Perjuangan Karawang.”

\section{B. Identifikasi Masalah}

Dari latar belakang yang telah dikemukakan di atas, terdapat beberapa permasalahan yang teridentifikasi yaitu :

1. Fungsi manajemen dalam pengelolaan Universitas Buana Perjuangan Karawang, belum sepenuhnya dilaksanakan.

2. Masih terdapat beberapa dosen Universitas Buana Perjuangan yang belum memenuhi standar yang telah ditetapkan oleh pemerintah

3. Masih rendahnya produktivitas kerja Dosen Universitas Buana Perjuangan Karawang sehingga hal ini dapat menghambat proses tumbuh dan berkembangnya lembaga pendidikan ini.

\section{Pembatasan Masalah.}

Penulis melakukan pembatasan masalah yakni dalam hal pengaruh fungsi manajemen terhadap prooduktivitas kerja Dosen Universitas Buana Perjuangan Karawang. 


\section{Rumusan Masalah}

Rumusan masalah penelitian ini yakni Bagaimana Pengaruh pelasanaan fungsi manajemen terhadap produktivitas kerja Dosen Universitas Buana Perjuangan Karawang?

\section{E. Tujuan Penelitian}

Penelitian ini bertujuan untuk Mengetahui Pengaruh pelaksanaan fungsi manajemen terhadap produktivitas kerja Dosen Universitas Buana Perjuangan Karawang?

\section{BAB II}

\section{LANDASAN TEORI}

\section{A. Fungsi Manajemen}

\section{Definisi Fungsi}

Dalam Wikipedia bahasa Indonesia, Fungsi di definisakan sebagai sekelompok aktivitas yang tergolong pada jenis yang sama berdasarkan sifat atau pelaksanaananya. Sedangkan dalam kamus Besar Bagasa Indonesia, Fungsi memiliki arti sebagai jabatan (pekerjaan) yang dilakukan dan kegunaan suatu hal.

Definisi fungsi menurut Sutarto (2008:22) adalah rincian tugas yang sejenis atau erat hubungannya satu sama lain untuk dilakukan oleh seorang pegawai tertentu yang masing-masing berdasarkan sekelompok aktivitas sejenis menurut sifat atau pelaksanaannya.

\section{Definisi Manajemen}

Secara etimologis, definisi manajemen di ungkapkan oleh Samsudun (2006 : 15). Menurut Samsudin, kata manajemen berasal dari Bahasa inggris. Yakni managemnent, yang dikembangkan dari kata to manage, artinya mengatur atau mengelola. Kata manage itu sendiri berasal dari Bahasa Italia, managio, yang diadopsi dari Bahasa latin managiare, yang berasal dari kata manus, artinya tangan

James A.F. Stoner (1994 : 8) mendefinisikan Manajemen sebagai proses perencanaan, pengorganisasian, pemimpinan dan pengendalian upaya anggota 
organisasi dan penggunaan semua sumber daya organisasi untuk mencapai tujuan yang telah ditetapkan.

Adapun Pengertian manajemen menurut Handoko (1999 : 8), adalah bekerja dengan orang-orang untuk menentukan, menginterpretasikan dan mencapai tujuantujuan organisasi dengan pelaksanaan fungsi-fungsi perencanaan (planning), Pengorganisasian (organizing), penyusunan personalia atau kepegawaian (staffing), pengarahan dan kepemimpinan (leading) dan pengawasan (controlling).

\section{Fungsi Manajemen}

Terdapat berbagai pendapat yang dikeuarkan oleh para ahli mengenai fungsi manajemen.

Menurut Terry (2010 : 9), fungsi manajemen dapat dibagi menjadi 4 (empat) bagian, yakni planning (perencanaan), organizing (pengorganisasian), actuating (pelaksanaan), dan controlling (pengawasan) :

1. Planning (Perencanaan)

a) Pengertian Planning

Planning (perencanaan) ialah penetapan pekerjaan yang harus dilaksanakan oleh kelompok untuk mencapai tujuan yang digariskan.

b) Proses Perencanaan

Proses perencanaan berisi langkah-langkah :

1) Menentukan tujuan perencanaan

2) Menentukan tindakan untuk mencapai tujuan

3) Mengembangkan dasat pemikiran kondisi mendatang

4) Mengidentifikasi cara untuk mencapai tujuan

5) Mengimplementasikan rencana tindakan dan mengevaluasi hasilnya.

2. Organizing (pengorganisasian),

a) Pengertian Pengorganisasian

Organisasi berasal dari kata Organon dalam Bahasa Yunani yang berarti alat, yaitu proses pengelompokan kegiatan-kegiatan untuk mencapai tujuan-tujuan dan penugasan setiap kelompok kepada seorang menajer (Terry \& Rue, 2010 : 82)

b) Komponan komponan Organisasi 
Ada empay komponen dari organisasi yang dapat diingat dengan kata

"WERE” (Work, Employees, Relationship dan Environment).

1) Work (pekerjaan) adalah fungsi yang harus dilaksanakan berasal dari sasaran-sasarn yang telah ditetapkan.

2) Employees (pegawai-pegawai), adalah setiap orang yang ditugskan untuk melaksanakan bagian tertantu dari seluruh pekerjaan.

3) Relationship (hubungan), merupakan hal penting di dalam organisasi. Hubungan Antara pegawai dengan pekerjaannya, interaksi Antara satu pegawai dengan pegawai lainnya dan unit kerja lainnya unit kerja pegawai dengan unit kerja lainnya merupakan hal-hal yang peka.

4) Environment (Lingkungan), adalah komponen terakhir yang mencakup sarana fisik dan sasaran umum di dalam lingkungan di mana para pegawai melaksanakan tusa-tugas mereka, lokasi, mesin, alat tulis kantor, dan sikap mental yang merupakan factor-faktor yang memebentuk lingkungan.

3. Actuating (pelaksanaan).

Pelaksanaan merupakan usaha menggerakkan anggota-anggota kelompok sedemikian rupa, singga mereka berkeinginan dan berusaha untuk mencapai tujuan yang telah direncanakan bersama. (Terry, $1993: 62$ )

4. Controlling (pengawasan)

a) Pengertian Controlling

Controlling atau pengawasan adalah penemuan dan penerapan cara dan alat untuk menjamin bahwa rencana telah dilaksanakan sesuai dengan rencana yang telah ditetapkan.

b) Tahap-tahap Pengawasan

Tahap-tahap pengawasan terdiri atas :

1) Penentuan standar

2) Penentuan pengukuran pelaksanaan kegiatan

3) Pengukuran pelaksanaan kegiatan

4) Pembanding pelaksanaan dengan standard an analisa penyimpanan

5) Pengambilan tindakan koreksi bila diperlukan 


\section{B. Produktiviyas Kerja}

\section{Definisi Produktivitas}

Produktivitas menurut Basu Swasta (1995 : 281), produktivitas didefinisikan sebagai suatu konsep yang menggambarkan hubungan Antara hasil (jumlah barang dan jasa yang diproduksi) dengan sumber (jumlah tenaga kerja, modal, tanah, energy dan sebagainya) yang dipakai untuk menghasilkan hasil tersebut.

Definisi Produktivitas menurut Manullang K dan Andreas G Munthe (1993 : 1) adalah sikap mental (Attitude on mind) yang mempunyai semangat untuk bekerja keras dan ingin memiliki kebiasaan untuk melakukan perbaikan.

\section{Definisi Produktivitas Kerja}

Produktivitas kerja di definisikan oleh J. Ravianto (1985 : 16) sebagai perbandingan Antara hasil yang dicapai dengan paran serta karyawan perusahaan per satuan waktu.

\section{Produktivitas Kerja Dosen}

\section{a) Eksistensi Dosen}

Undang-undang No. 14 tahun 2005 tentang Guru dan Dosen, menyatakan bahwa Dosen adalah pendidik profesioal dan ilmuan dengan tugas mentransformasikan, mengembangkan dan menyebarluaskan ilmu pengetahuan, teknologi dan seni melalui pendidikan, penelitian dan pengabdian kepada masyarakat.

\section{b) Kedudukan Dosen}

Kedudukan dosen berdasarkan Undang-undang No. 14 tahun 2005 pasal 3, tentang guru dan dosen adalah :

1) Dosen mempunyai kedudukan sebagai tenaga professional pada janjang pendidikan tinggi yang diangkat sesuai dengan peraturan perundang-undangan.

2) Pengakuan kedudukan dosen sebagai tenaga professional sebagaimana dimaksud pada ayat (1) dibuktikan dengan sertifikat pendidik.

3) Dalam UU No. 14 tahun 2005 tentang Guru dan Dosen Pasal 46 butir 2 a dan b dinyatakan bahwa Dosen memiliki kualifikasi akademik minimum: 
1. Lulusan program magister untuk program diploma atau program sarjana; dan

2. Lulusan program doktor untuk program pascasarjana.

\section{c) Kompetensi Dosen}

Kompetensi Dosen adalah seperangkat pengetahuan, keterampilan dan perilaku yang harus dimiliki, dihayati dan dikuasai oleh dosen dalam melaksanakan tugas keprofesionalan (UU No. 14 tahun 2005 tentang Guru dan Dosen, Pasal 1 ayat 10)

\section{d) Beban Kerja dan Tugas Utama Dosen}

Beban kerja dan tugas dosen tertuang dalam Pedoman Beban Kerja Dosen dan Evaluasi Pelaksanaan Tridharma Perguruan Tinggi yang dikeluarkan oleh Direktorat Jenderal Pendidikan Tinggi Departemen Pendidikan Nasional tahun 2010 halaman $6-8$ sebagai berikut :

\section{1) Beban Kerja Dosen}

Tugas utama dosen adalah melaksanakan tridharma perguruan tinggi dengan beban kerja paling sedikit sepadan dengan 12 (dua belas) sks dan paling banyak 16 (enam belas) sks pada setiap semester sesuai dengan kualifikasi akademiknya dengan ketentuan sebagai berikut :

(a) Tugas melakukan pendidikan dan penelitian paling sedikit sepadan dengan 9 (sembilan) sks yang dilaksanakan di perguruan tinggi yang bersangkutan.

(b) Tugas melakukan pengabdian kepada masyarakat dapat dilaksanakan melalui kegiatan pengabdian kepada masyarakat yang diselenggarakan oleh perguruan tinggi yang bersangkutan atau melalui lembaga lain sesuai dengan peraturan perundang-undangan.

(c) Tugas penunjnag tridharma perguruan tinggi dapat diperhitungkan sks nya sesuai dengan peraturan perundang-undangan.

(d) Tugas melakukan pengabdian kepada masyarakat dan tugas penunjang paling sedikit sepadan dengan 3 (tiga) sks.

Pemimpin perguruan tinggi berkewajiban memberikan kesempatan kepada dosen untuk melaksanakan tridharma perguruan tinggi. Dosen yang mendapat penugasan sebagai pimpinan perguruan tinggi sampai dengan tingkat 
jurusan diwajibkan melaksanakan tridharma pendidikan paling sedikit sepadan dengan 3 (tiga) sks.

\section{2) Tugas Utama Dosen}

Tugas melakukan pendidikan merupakan tugas di bidang pendidikan dan pengajaran yang dapat berupa :

(a) Melaksanakan perkuliahan/tutorial dan menguji serta menyelenggrakan kegiatan pendidikan di laboratorium, praktik keguruan, praktik bengkel/studio/kebun percobaan/teknologi pangajaran;

(b) Membimbing seminar mahasiswa;

(c) Membimbing kuliah kerja nyata $(\mathrm{KKN})$, praktek kerja naya $(\mathrm{PKN})$, praktek kerja lapangan (PKL);

(d) Membimbing tugas akhir penelitian mahasiswa termasuk membimbing pembuatan laporan hasil penelitian tugas akhir;

(e) Penguji pada ujian akhir;

(f) Membina kegiatan mahasiswa di bidang akademik dan kemahasiswaan

(g) Mengembangkan program perkuliahan

(h) Mengembankan bahan pengajaran

(i) Menyampaikan orasi ilmiah

(j) Membina kegiatan mahasiswa di bidang akademik dan kemahasiswaan

(k) Membimbing dosen yang lebih rendah jabatannya;

(1) Melaksanakan kegiatan datasering dan pencangkokan dosen

Tugas melakukan penelitian merupakan tugas di bidang penelitian dan pengembangan karya ilmiah yang dapat berupa :

(a) Menghasilkan karya penelitian;

(b) Menerjemahkan/menyadur buku ilmiah;

(c) Mengedit/menyunting karya ilmiah;

(d) Membuat rancangan dan karya teknologi;

(e) Membuat rancangan karya seni.

Tugas melakukan pengabdian kepada masyarakat dapat berupa

(a) Menduduki jabatan pimpinan dalam lembaga pemerintahan/pejabat Negara sehingga harus dibebaskan dari jabatan organiknya; 
(b) Melaksanakan pengembangan hasil pendidikan dan penelitian yang dapat dimanfaatkan oleh masyarakat;

(c) Memberi latihan/penyuluhan/penataran pada masyarakat;

(d) Memberi pelayanan kepada masyarakat atau kegiatan lain yang menunjang pelaksanaan tugas umum pemerintah dan pebangunan;

(e) Membuat/menulis karya pengabdian kepada masyarakat.

Tugas penunjang tridharma perguruan tinggi dapat berupa

(a) Menjadi anggota dalam suatu panitia/badan pada perguruan tinggi;

(b) Menjadi anggota panitia/badan pada lebaga pemerintah;

(c) Menjadi anggota organisasi profesi;

(d) Mewakili perguruan tinggi/lembaga pemerintah duduk dalam panitia antar lembaga;

(e) Menjadi anggota delegasi nasional ke pertemuan internasional

(f) Berperan serta aktif dalam pertemuan ilmiah;

(g) Mendapat tanda jasa/penghargaan;

(h) Menulis buku pelajaran SLTA ke bawah;

(i) Mempunyai prestasi di bidang olahraga/kesenian/social.

\section{Kerangka Pemikiran}

Dosen merupakan salah satu unsur yang memiliki peran penting dalam penyelenggraan pendidikan tinggi. pelaksanaan fungsi manajemen secara teoritis dapat membangun produktivitas kerja dosen sebagai ujung tombak dalam penyelenggaraan pendidikan tinggi.

Tugas seorang dosen tidak hanya sekedar memberikan pengajaran di kelas, tapi harus mampu melaksanakan tugas lainnya yaitu tri dharma perguruan tinggi. Jadi selain mengajar, ada tugas lain yang menjadi tanggung jawab seorang dosen, yaitu penelitian serta pengabdian kepada masyrakat.

Pelaksanaan fungsi manajemen dalam pengelolaan pendidikan tinggi menjadi dasar terciptanya produktivitas kerja dosen sehingga tri dharma perguruan tinggi sebagai tugas utama dosen dapat terwujud 
Gambar 2.1

Kerangka Pemikiran

Fungsi Manajemen (Variabel X)

Produktivitas Kerja Dosen (Variabel Y)

\section{Hipotesis}

Dari kerangka pemikiran tersebut dapat dikemukakan hipotesis bahwa Fungsi manajemen berpengaruh terhadap produktivitas kerja Dosen.

\section{BAB III}

\section{METODE PENELITIAN}

\section{A. Tempat Penelitian}

Penelitian ini dilakukan di Universitas Buana Perjuangan Karawang yang beralamat di Jl. HS Ronggowaluyo Telukjambe Timur Karawang.

\section{B. Sumber Data}

\section{Populasi}

Populasi penelitian ini adalah seluruh Dosen tetap Universitas Buana Perjuangan Karawang sebanyak 106 orang dengan data sebagai berikut :

Tabel 3.1

Data Jumlah Dosen Tetap

\begin{tabular}{|c|l|c|}
\hline No & Program Studi & Jumlah \\
\hline 1 & Akuntansi & 9 \\
2 & Farmasi & 9 \\
3 & Ilmu Hukum & 10 \\
4 & Manajemen & 18 \\
5 & Psikologi & 9 \\
6 & PPKN & 8 \\
7 & PGSD & 13 \\
8 & Sistem Informasi & 9 \\
9 & Teknik Informatika & 9 \\
10 & Teknik Industri & 12 \\
\hline & Jumlah & 106 \\
\hline
\end{tabular}

Sumber : Kepegawaian Universitas Buana Perjuangan Karawang 2017 


\section{Sampel}

Arikunto (2005 : 117) mengatakan sampel adalah bagian daripopulasi. Sampel penelitian adalah bagian dari populasi yang diambil sebagai sumber data dan dapat mewakili seluruh populasi. Selanjutnya Arikunto (2005 : 120) mengatakan untuk sekedar ancar ancar maka apabila subjek kurang dari 100 orang, maka lebih baik diambil semua sehingga penelitian ini merupakan penelitian populasi.

Dikarenakan jumlah populasi dari penelitian ini lebih dari 100 orang, maka pengambilan sampel menggunakan sampel acak (random sampling). Adapun teknik pengambilan sampel menggunakan rumus dari Taro Yamane atau Slovin (Riduwan, 2007 : 65) sebagai berikut :

$$
\mathrm{n}=\frac{\mathrm{N}}{\mathrm{N} \cdot \mathrm{d}^{2}+1} \quad \begin{aligned}
& \begin{array}{l}
\text { Keterangan : } \\
\mathrm{n}=\text { Jumlah sampel } \\
\mathrm{N}
\end{array}=\text { Jumlah Populasi = } 106 \text { Responden } \\
& \mathrm{d}^{2}=\text { Presisi (ditetapkan } 10 \% \text { dengan tingkat } \\
& \text { kepercayaan } 95 \%)
\end{aligned}
$$

Berdasarkan rumus di atas, diperoleh jumlah sampel sebagai berikut :

$$
\mathrm{n}=\frac{\mathrm{N}}{\mathrm{N} \cdot \mathrm{d}^{2}+1}=\frac{106}{(106) \cdot 0,10^{2}+1}=\frac{106}{2,06}=51,45
$$

Berdasarkan hasil perhitungan dari rumus di atas, maka sampel yang diambil sebanyak 51,45 orang dosen dibulatkan menjadi 52 orang.

\section{Rancangan / Desain Penelitian}

Rancangan penelitian ini yaitu dengan menggunakan metode deskriptif korelasional yaitu pendekatan studi kasus dan kausal yang akan menganalisis tentang pengaruh antara variabel bebas (independent variable) terhadap variabel terikat (dependent variable). Variabel bebas dalam penelitian ini yaitu Fungsi Manajemen (X), dan variable terikatnya yaitu produktivitas kerja dosens (Y).

\section{Definisi Konseptual dan Operasional Variabel}

\section{Definisi Konseptual}

Sukamto Reksohadiprodjo (1998: 13) merumuskan fungsi manajemen sebagai suatu usaha merencanakan, mengorganisir, mengarahkan, mengkoordinir 
serta mengawasi kegiatan dalam suatu organisasi agar tercapai tujuan organisasi secara efisien dan efektif.

Konsep produktivitas kerja diutarakan oleh J. Ravianto (1985 : 16) yang mengatakan bahwa produktivitas kerja karyawan diartikan sebagai perbandingan Antara hasil yang dicapai dengan paran serta karyawan perusahaan per satua waktu.

Produktivitas kerja dosen tertuang dalam serangkaian hasil kerja dan tugas dosen sebagaimana tercantum dalam penjelasan pedoman beban kerja dosen dan evaluasi pelaksanaan tridharma perguruan tinggi Direktorat jenderal Pendidikan Tinggi Departemen Pendidikan NAsional tahiun 2010 (harlaman 6 - 8) sebagai berikut :

\section{a. Pendidikan,}

Tugas melakukan pendidikan merupakan tugas di bidang pendidikan dan pengajaran yang dapat berupa :

(1) Melaksanakan perkuliahan/tutorial dan mebuji serta meyelenggarakan kegiatan pendidikan di laboratorium, praktik keguruan, praktik benghkel/studio/kebunj percobaan/teknologi pengajaran;

(2) Memvbimbing rugas akhir penelitian mahasiswa termasuk membimbing pembuatan laporan hasi; penelitian tugas akhir;

(3) Membina kegiatan mahasiswa di bidang akademik dan kemahasiswaan;

(4) Mengembagkan bahan pengajaran;

\section{b. Penelitian}

Tugas melakukan penelitian merupakan tugas bidang penelitian dan pengembangan karya ilmiah yang dapat berupa :

(1) Menghasilkan karya ilmiah

(2) Menerjemahkan/menyadur buku ilmiah

(3) Mengedit/menyunting karya ilmiah

\section{c. Pengabdian kepada masyarakat}

Tugas melakukan pengabdian kepada masyarakat dapat berupa

(1) Merngembangkan hasil penelitian

(2) Memberikan penyuluhan pada masyarakat

(3) memberi pelayanan pada masyarakat; 


\section{d. tugas penunjang tridarma}

Tugas penunjang tridarma perguruan tinnggi dapat berupa

(1) menjadi anggota dalam suatu penitian/badan pada perguruan tinggi/pemerintah;

(2) menjadi anggota organisasi profesi;

(3) mewakili perguruan tinggi/lembaga pemerintah duduk dalam panitia antar lembaga.

\section{Operasional Variabel}

Operasional variable penelitian untuk masing masing varabel dapat dilihat pada tabel di bawah ini:

Tabel 3.2

Operasionalisasi Variabel Fungsi Manajemen

\begin{tabular}{|c|c|c|c|}
\hline Variabel & Dimensi & Indikator & $\begin{array}{c}\text { Nomor } \\
\text { Pertanyaan }\end{array}$ \\
\hline \multirow[t]{4}{*}{$\begin{array}{l}\text { Fungsi } \\
\text { Manajemen (X) }\end{array}$} & $\begin{array}{l}\text { 1. Perencanaan } \\
\text { (Planning) }\end{array}$ & $\begin{array}{l}\text { 1. Menentukan tujuan } \\
\text { perencanaan; } \\
\text { 2. Menentukan tindakan untuk } \\
\text { mencapai tujuan; } \\
\text { 3. Mengembangkan dasar } \\
\text { pemikiran kondisi mendatang; } \\
\text { 4. Mengidentifikasi cara untuk } \\
\text { mencapai tujuan; } \\
\text { 5. Mengiplementasi rencana } \\
\text { tindakan dan mengevaluasi } \\
\text { hasilnya }\end{array}$ & $\begin{array}{l}1 \\
2 \\
3 \\
4 \\
5\end{array}$ \\
\hline & $\begin{array}{l}\text { 2. Pengorganisasia } \\
\mathrm{n} \text { (Organizing) }\end{array}$ & $\begin{array}{l}\text { 1. Pekerjaan;; } \\
\text { 2. Pembagian tugas pekerjaan; } \\
\text { 3. Hubungan Antara pegawai; } \\
\text { 4. Lingkungan tempat kerja; }\end{array}$ & $\begin{array}{l}6 \\
7 \\
8 \\
9\end{array}$ \\
\hline & $\begin{array}{l}\text { 3. Pelaksanaan } \\
\text { (Actuating) }\end{array}$ & Pelaksanaan tugas pekerjaan & 10 \\
\hline & $\begin{array}{l}\text { 4. } \begin{array}{l}\text { Pengawasan } \\
\text { (Controlling) }\end{array}\end{array}$ & $\begin{array}{l}\text { 1. Penentuan standar; } \\
\text { 2. Penentuan pengukuran } \\
\text { pelaksanaan kegiatan; } \\
\text { 3. Pengukuran pelaksanaan } \\
\text { kegiatan; } \\
\text { 4. Pembanding pelaksanaan dengan } \\
\text { standar; } \\
\text { 5. Analisa penyimpangan; } \\
\text { 6. Pengambilan tindakan koreksi. }\end{array}$ & $\begin{array}{l}11 \\
12 \\
13 \\
14 \\
15 \\
16\end{array}$ \\
\hline
\end{tabular}

Sumber : Terry (2010: 9). Hasil pengolahan data (2017) 
Tabel 3.3

Operasionalisasi Produktivitas Kerja Dosen

\begin{tabular}{|c|c|c|c|}
\hline Variabel & Dimensi & Indikator & $\begin{array}{c}\text { Nomor } \\
\text { Pertanyaan }\end{array}$ \\
\hline \multirow[t]{4}{*}{$\begin{array}{l}\text { Prtoduktivitas } \\
\text { Kerja Dosen (Y) }\end{array}$} & $\begin{array}{l}\text { 1. Pendidikan dan } \\
\text { pengajaran }\end{array}$ & $\begin{array}{l}\text { (1) Melaksankan perkuliahan; } \\
\text { (2) Membimbing mahasiswa dalam } \\
\text { bidang akademik; } \\
\text { (3) Mebina kegiatan mahasiswa; } \\
\text { (4) Mengembangkan bahan } \\
\text { pengaiaran. }\end{array}$ & $\begin{array}{l}1 \\
2 \\
3 \\
4\end{array}$ \\
\hline & 2. Penelitian & $\begin{array}{l}\text { (1) Menghasilkan karya penelitian; } \\
\text { (2) Menerjemahkan/menyadur buku } \\
\text { ilmiah; } \\
\text { (3) Mengedit/menyunting karya } \\
\text { ilmiah; }\end{array}$ & $\begin{array}{l}5 \\
6 \\
7\end{array}$ \\
\hline & $\begin{array}{l}\text { 3. Pengabdian } \\
\text { pada } \\
\text { masyarakat }\end{array}$ & 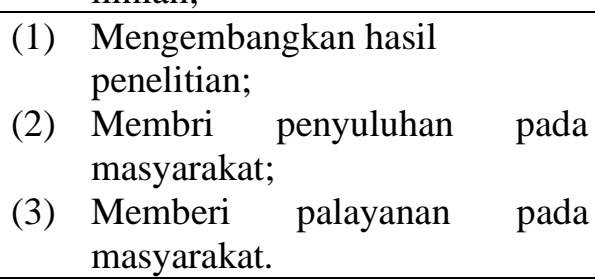 & $\begin{array}{c}8-9 \\
10-11 \\
12\end{array}$ \\
\hline & $\begin{array}{l}\text { 4. Tugas } \\
\text { penunjang } \\
\text { lainnya }\end{array}$ & $\begin{array}{l}\text { (1) Menjadi anggota dalam suatu } \\
\text { panitia pada perguruan } \\
\text { tinggi/pemerintah; } \\
\text { (2) Menjadi anggota organisasi } \\
\text { profesi; } \\
\text { (3) Mewakili perguruan tinggi } \\
\text { duduk dalam panitia Antara } \\
\text { lembaga. }\end{array}$ & $13 \& 14$ \\
\hline
\end{tabular}

Sumber : Dirjen dikti Depdiknas tahun 2010 dalam Penjelasan Pedoman Beban Kerja

Dosen dan Evaluasi Pelaksanaan Tridharma Perguruan Tinggi, (halaman 6 -8).

\section{e. Instrumen Penelitian}

\section{Riset Lapangan (Field Research)}

\section{a. Wawancara (Interview)}

Wawancara, sebagai teknik komunikasi langsung untuk memperoleh data yang diperlukan serta ditujukan kepada dosen Universitas Buana Perjuangan Karawang.

\section{b. Observasi (Obsevation)}

Riset lapangan ini dilakukan dengan cara mengadakan pengamatan secara langsung dan melakukan pencatatan akan data data yang diperoleh yang berhubungan dengan kajian penelitian yakni mengenai fungsi manajemen dan produktivitas kerja dosen. 


\section{c. Kuisioner}

Kuesioner, yaitu daftar pertanyaan yang dibuat dalam bentuk sederhana dengan menggunakan pertanyaan tertutup dan yang diberikan kepada Dosen Universitas Buana Perjuangan Karawang sebagai responden.

\section{d. Studi Kepustakaan (Library Research)}

Studi kepustakaan, yaitu data yang diperoleh dengan cara mempelajari, meneliti, dan mengkaji literatur yang ada kaitannya dengan masalah yang diteliti.

\section{f. Teknik Analisis}

\section{Teknik Skala}

Untuk mengukur data yang diperoleh dari angket/kuesioner yang terkumpul, pendapat responden atas pertanyaan diberi nilai dengan skala Likert, sebagaimana diungkapkan oleh sugiyono (2008 : 134) bahwa skala Likert digunakan untuk mengukur sikap, pendapat dan persepsi seseorang atau sekelompok orang tentang fenomena sosial.

Skala Likert ini memberikan nilai (bobot) skala untuk setiap alternatif jawaban yang berjumlah 5 (lima) harapan. Dari masing masing variable (X dan Y) terdiri dari 16 pertanyaan. Nilai atau skor dari alternatif jawaban adalah :

Tabel 3.4

Pemberian Bobot Nilai Kuisioner

\begin{tabular}{|c|c|c|}
\hline Bobot nilai & Fungsi Manajemen & $\begin{array}{c}\text { Produktivitas Kerja } \\
\text { Dosen }\end{array}$ \\
\hline $\mathbf{5}$ & Sangat Baik & Sangat Baik \\
\hline 4 & Baik & Baik \\
\hline 3 & Cukup Baik & Cukup Baik \\
\hline 2 & Kurang Baik & Kurang Baik \\
\hline 1 & Tidak baik & Tidak Baik \\
\hline
\end{tabular}

Sumber : Hasil Pengolahan, 2017

Untuk mengetahui besarnya skor kriteria jawaban responden, digunakan skala parameter untuk skor terendah yaitu $52 \times 1 \times 16=832$ dan skor tertinggi yaitu : $52 \times 5 \times 16=4160$ sebagai mana dapat terlihat pada tabel 3.6 berikut ini : 
Tabel 3.5

Skor Kriteria Jawaban Responden

\begin{tabular}{|c|c|c|}
\hline Interval Data & Fungsi Manajemen & Produktivitas Kerja \\
\hline $3328-4160$ & Sangat Baik & Sangat Baik \\
\hline $2496-3328$ & Baik & Baik \\
\hline $1164-2496$ & Cukup Baik & Cukup Baik \\
\hline $832-1164$ & Kurang Baik & Kurang Baik \\
\hline $0-832$ & Tidak Baik & Tidak Baik \\
\hline
\end{tabular}

Sumber : Hasil Pengolahan Data (2017)

\section{Analisis Deskriptif}

Analisis deskriptif merupakan pembahasan dan penggambaran dari data yang diperoleh dengan cara menjelaskan hasil penelitian mengenai objek yang diteliti dengan data yang diperoleh berdasarkan teori, pendapat dan pandangan para ahli.

\section{Uji Validitas dan Reliabilitas}

Instrumen yang digunakan dalam penelitian ini adalah angket, yang bertujuan untuk mengetahui pendapat seseorang mengenai sesuatu hal.

Suatu amgket dikatakan valid jika pertanyaan pada suatu angket mampu mengungkapkan sesuatu yang akan diukur oleh angket tersebut (santoso, 2001) dan suatu angket dikatakan reliable jika jawaban seseorang terhadap pertanyaan adalah konsisten atau stabil dari waktu ke waktu. (santoso, 2001)

Validitas adalah suatu indeks yang menunjukkan alat ukut itu benarbenar mengukur apa yang diukur. Untuk mengetahui tingkat validitas alat ukur penelitian menggunakan rumus korelasi product moment (Notoatmodjo, 2012)

Penhujian validitas dan reliabilitas adalah proses menguji butir-butir pertanyan yang ada dalam sebuah angket. Pengukuran dilakukan dengan menggunakan metode reliability analysis-scale (alpha) dengan bantuan program SPSS versi 18.

Hasil uji validitas dapat dilihat pada output Bivariate Analysis-Correlate atau pada kolom "correlated Item-Total Correlation" pada out put Reliability Abalysius-Scale (Alpha). Angka hasil pada kolom tersebut disebut $\mathbf{r}_{\text {hitung. }}$.

Dikatakan valid jika $r_{\text {hitung }}$ adalah positif dan lebih besar dari $r_{\text {table }}\left(r_{\text {hasil }}\right.$

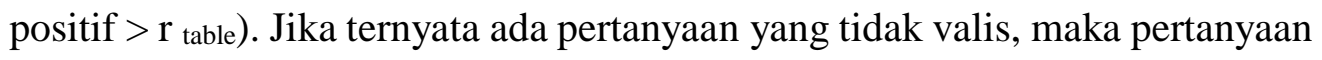


tersebut akan dibuang dan pengujian diulang kembali sampai hasilnya menunjukkan valid.

Hasil uji reliabilitas dapat dilihat pada hasil out put di dalam kolom Alpha of item deleted. Angka pada kolom tersebut adalah rhitung yang disebut alpha. Dikatakan reliable jika skor bitur berkorelasi positif dengan skor factor atau hasil angka alpha ( $\left.r_{\text {hitung }}\right)$ positif dan lebih besar dari $r_{\text {tabel }}\left(\right.$ alpha $\left.>r_{\text {tabel }}\right)$, atau angka alpha > standar level lain yang ditentukan peneliti. JIka terdapat angka alpha yang tidak reliable, pertanyaan dikeluarkan dan pengujian diulang kembali dengan mengambil pertanyaan-pertanyaan dengan angka alpha yang reliable.

\section{Analisis Korelasi}

Analisa korelasi digunakan untuk mengukur keeratan hubungan linier antara dua variabel. Analisa korelasi dalam penelitian ini dengan menggunakan metode regresion linier-analysis, hasil analisa dapat dilihat pada out putcorrelation.

Untuk mengetahui tingkat hubungan dari hasil analisa korelasi dapat dilihat pada tabel 3.7 berikut :

Tabel 3.7

Pedoman untuk Memberikan Interpretasi Koefisien Korelasi

\begin{tabular}{|c|c|}
\hline Interval Koefisien & Tingkat Hubungan \\
\hline $0,000-0,199$ & Sangat Rendah \\
\hline $0,200-0,399$ & Rendah \\
\hline $0,400-0,599$ & Sedang \\
\hline $0,600-0,799$ & Kuat \\
\hline $0,800-1,000$ & Sangat Kuat \\
\hline
\end{tabular}

Sumber : Sugiyono $(2003: 214)$

\section{Analisa Regresi Linier (Uji F)}

Analisis linier dalam penelitian ini dengan menggunakan soft ware program SPSS versi 18 dengan metode regression linier-analysis, hasil analisa dapat dilihat pada out put model summary, model anova dan model coefficients. Dalam perhitungan ini perhitungan statistik menggunakan model analisis regresi sederhana :

$$
\hat{\mathrm{Y}}=\mathrm{a}+\mathrm{bX}
$$




$$
\begin{array}{ll}
\hat{\mathrm{Y}} & : \text { Fungsi Manajemen } \\
\mathrm{X} & : \text { Prodduktivitas Kerja Dosen } \\
\mathrm{a} & : \text { Parameter konstanta } \\
\mathrm{b} & : \text { Koefisien regrasi / nilai parameter }
\end{array}
$$

\section{Analisa Koefisien Determinasi}

Hasil analisa koefisien determinasi ini dapat dilihat pada out put model summary pada kolom $\mathrm{R}$ square. Atau dapat dihitung dengan menggunakan rumus koefisien determinasi sebagaimana diungkapkan oleh Sri Mulyono (1998 : 213) sebagai berikut:

$$
\mathrm{CD}=\mathrm{R}^{2} \times 100 \%
$$

Keterangan : $\mathrm{CD}=$ Koefisien Determinasi

$$
\mathrm{R}=\text { Koefisien Korelasi }
$$

\section{Hipotesis Statistik}

Hipotesis statistik dalam penelitian ini adalah :

$\mathrm{H}_{0}: \beta=0$; Tidak terdapat pengaruh variabel bebas (Fungsi Manajemen) terhadap variabel terikat (Produktivitas Kerja Dosen)

Ha: $\beta \neq 0$; Terdapat pengaruh variabel bebas (Fungsi Manajemen) terhadap variable terikat (Produktivitas Kerja Dosen)

Kriteria pengujian : $\mathrm{H}_{0}$ ditolak jika sig $\mathrm{t} \leq \alpha$ dengan $\alpha=5 \%(0.05)$

\section{BAB IV}

\section{HASIL PENELITIAN}

\subsection{Uji Validitas dan Reliabilitas}

Uji validitas dengan tahap signifikansi 5\% untuk koefesien korelasi jika $\mathrm{r}$ hitung > $r$ tabel jika dibanding maka butir soal dikatakan valid, bila $r$ hitung positif dan lebih besar dari nilai $r$ tabel, maka item pertanyaan pada kuesioner penelitian dikatakan valid. Uji ini akan dilakukan dengan menggunakan aplikasi statistik.

Dalam uji validitas, setiap item pertanyaan dilakukan uji validitas terhadap total skor seluruh pertanyaan tersebut dengan menggunakan uji Pearson Product Moment. Apabila hasil dari uji tersebut untuk setiap item pertanyaan ternyata signifikan $(\mathrm{p}>5 \%)$, maka item pertanyaan tersebut sudah valid dan bisa 
digunakan, tetapi apabila tidak signifikan $(\mathrm{p}<5 \%)$ maka item pertanyaan tersebut tidak valid dan harus didrop dari kuesioner. Uji signifikasi dengan membandingkan nilai $\mathrm{r}$ hitung dengan $\mathrm{r}$ tabel product moment dimana didapatkan $r$ tabel yaitu 0,273 .

Hasil uji validitas kuesioner yang dilakukan peneliti didapatkan bahwa keseluruhan hasil penelitian validitas diketahui bahwa setiap butir pertanyaan untuk uji fungsi manajemen dengan produktivitas kerja dosen sebanyak masingmasing 16 indikator dinyatakan valid. Hal ini karena nilai $\mathrm{r}$ hitung masingmasing item soal lebih besar dari $r$ tabel $(0,273)$ jika dilihat dari soal kuesioner yang dinyatakan valid secara keseluruhan maka layak untuk dilanjutkan uji reabilitas dan dipergunakan sebagai instrumen penelitian.

Reliabilitas ialah indeks yang menunjukkan sejauh mana suatu alat pengukur dapat dipercaya atau dapat diandalkan, tetap konsisten atau tetap asas (ajeg) bila dilakukan pengukuran dua kali atau lebih terhadap gejala yang sama, dengan menggunakan alat ukur yang sama. Uji reabilitas kuesioner dilakukan dengan teknik alpha (Notoatmodjo, 2012).

Hasil perhitungan rumus ini kemudian dianalisa dalam aplikasinya, bila hasil perhitungan Cronbach Alpha $(\alpha)>0,6$ atau mendekati angka 1 maka instrumen penelitian dikatakan reliabel. Uji ini akan dilakukan dengan menggunakan system komputer (SPSS).

Hasil pengujian reabilitas diperoleh nilai Cronbach Alpha $(\alpha)$ untuk variabel fungsi manajemen dan produktivitas kerja dosen $\alpha=0,961$ berarti $>0,6$ maka kuesioner tersebut dikatakan reliabel sehingga dapat digunakan sebagai kuesioner dalam penelitian.

\subsection{Analisa Univariat}

Hasil analisis univariat pada tabel 4.1 menunjukkan bahwa rata-rata pada skor variabel fungsi manajemen adalah 66,79 dengan standard deviasi sebesar 5,270. Skor terkecil dari perhitungan fungsi manajemen adalah 57 dan skor terbesar adalah 80. Berdasarkan estimasi interval dapat disimpulkan bahwa $95 \%$ diyakini bahwa rata-rata fungsi manajemen adalah diantara 65,32 sampai dengan 68,26. 
Sedangkan pada variabel produktivitas kerja dosen, rata-ratanya adalah 67,29 dengan standard deviasi sebesar 5,535. Interval skor minimum dan maksimum dari perhitungan skor produktivitas kerja dosen yaitu 48 sampai dengan 80. Kemudian estimasi interval disimpulkan bahwa $95 \%$ diyakini bahwa rata-rata produktivitas kerja dosen berkisar antara 65,75 sampai dengan 68,83 .

Tabel 4.1

Analisa Univariat Fungsi Manajemen dan Produktivitas Kerja Dosen

\begin{tabular}{|c|c|c|c|c|c|c|}
\hline No & Variabel & Mean & $\begin{array}{c}\text { Standar } \\
\text { Deviasi }\end{array}$ & Minimal & Maksimal & 95\% CI \\
\hline 1. & Fungsi Manajemen & 66,79 & 5,270 & 57 & 80 & $65,32-68,26$ \\
\hline 2. & Produktivitas Kerja Dosen & 67,29 & 5,535 & 48 & 80 & $65,75-68,83$ \\
\hline
\end{tabular}

Sumber : Hasil Pengolahan Data Melaui Program SPSS V 18

\subsection{Analisa Bivariat Uji Korelasi dan Regresi}

Tabel 4.2 menunjukkan bahwa korelasi yang terjadi antara variabel fungsi manajemen dan produktivitaskerja dosen memiliki nilai sebesar 0,662. Artinya arah hubungan kedua variabel tersebut positif, apabila variabel fungsi manajemen naik maka variabel produktivitas kerja dosen juga akan naik, dimana jika semakin baik fungsi manajemen dijalankan, maka produktivitas kerja dosen akan semakin baik pula, begitu juga sebaliknya. Sedangkan kekuatan korelasi antara variabel X dan Y adalah kuat.

Dengan nilai koefisien determinasi sebesar 0,438, menjelaskan bahwa persamaan regresi yang diperolah dapat menerangkan $43,8 \%$ variasi produktivitas kerja dosen atau bisa dikatakan bahwa persamaan regresi yang diperoleh cukup baik untuk menjelaskan variabel fungsi manajemen. Hasil uji statistik didapatkan terdapat pengaruh variabel bebas (fungsi manajemen) terhadap variabel terikat (produktivitas kerja dosen) dengan nilai p-value sebesar 0,0005. 
Tabel 4.2

Ringkasan Hasil Pengolahan Data Regresi

\begin{tabular}{lccccc}
\hline \multicolumn{1}{c}{ Keterangan } & B & Standar Eror & $\mathbf{t}_{\text {hitung }}$ & Sig & Keterangan \\
\hline Constant & 20,843 & 7,457 & 2,795 & 0,007 & Signifikan \\
Fungsi Manajemen $(\mathrm{X})$ & 0,695 & 0,111 & 6,248 & 0,0005 & Signifikan \\
Nilai $\mathrm{R}=0,662$ & & Sig F $=0,0005$ & & Jumlah Sampel $=52$ \\
Nilai $\mathrm{R}^{2}=0,438$ & & F hitung $=39,034$ & & $\alpha$ \\
Persamaan Regresi $\mathrm{Y}=0,05$ & \\
Produktivitas Kerja Dosen $=20,843+0,695 *$ Fungsi Manajemen $+\mathrm{e}$ & $\beta_{1}+\mathrm{e}$ & & \\
\end{tabular}

Sumber : Hasil Pengolahan Data Melaui Program SPSS V 18

Setelah melakukan analisa statistik terhadap produktivitas kerja dosen dan fungsi manajemen, dengan nilai konstan sebesar 20,843 dan nilai $b=0,695$ didapatkan persamaan regresinya sebagai berikut:

$$
\mathrm{Y}=\beta_{0}+\beta_{1} \mathrm{X}_{1}+\mathrm{e}
$$

Produktivitas Kerja Dosen $=20,843+0,695 *$ Fungsi Manajemen + e

Dimana:

c. Konstanta $\beta_{0}$ sebesar 20,843 artinya jika faktor fungsi manajeman konstan atau sama dengan 0 (nol), maka besarnya produktivitas kerja dosen adalah 20,843 satuan.

d. Nilai $\beta_{1}$ yang merupakan koefisien regresi dari variabel $\mathrm{X}_{1}$ (fungsi manajemen) sebesar 0,695 artinya jika terjadi peningkatan fungsi manajemen sebesar 1 satuan, maka produktivitas kerja dosen akan mengalami kenaikan atau peningkatan sebesar 0,695 satuan.

\section{DAFTAR PUSTAKA}

Basu Swasta, Pengatar Bisnis modern,Jakarta, Liberty. 1995

Hasibuan, Malayu SP, Manajemen: Dasar, Penertian dan Masalah, Edisi Revisi, Bumi Aksara, Jakarta, 2009

Handoko, T. Hani. Manajemen, BPFE Yogyakarta, 1999 
J Ravianto, Produktivitas dan Tenaga Kerja Indonesia, Jakarta. Lembaga Sarana Informasi Usaha dan Produktivitas. 1985

James A.F Stoner, R. Edwar Freeman dan Danier R. Gilbert JR, Manajemen, Jilid 1 (Edisi Bahasa Indonesia). PT. Prenhallindo, Jakarta. 1996.

James A.F Stoner. Manajemen Jilid 1. Erlangga. Jakarta. 1994

Prof. Dr. Sukamto Reksohadiprodjo, Dasar-dasar Manajmen. Edisi 5. BPFE Yogyakarta. 1998

Sinungun Muchdarsyah, produktivitas Apa dan Bagaimana, Caretakan ke 2. Bumi Aksara. Jakarta. 2005

Sutarto, Dasar-dasar Organisasi. Gajah Mada University Press. Yogyakarta 2008

Terry, George R. prinsip-prinsip Manajemen. Bumi Aksara, Jakarta 1993.

Terry, Georga dan Leslie W Rue. Dasar-dasar Manajemen. Edisi ke sebelas.

Bumi Aksara. Jakarta. 2010

Undang-undang Republik Indonesia Nomor 14 tahun 2005 Tentang Guru dan Dosen

Pedoman Beban Kerja Dosen dan Evaluasi Pelaksanaan Tridharma Perguruan Tinggi . Direktorat Jenderal Pendidikan Tinggi Departemen Pendidikan Nasional tahun 2010 